\title{
加速劣化ハザードモデル：コンクリート 中性化予測への適用
}

\author{
田中尚 ${ }^{1} \cdot$ 藤森裕二 $^{2} \cdot$ 貝戸清之 ${ }^{3} \cdot$ 小林潔司 $^{4} \cdot$ 安野貴人 ${ }^{5}$ \\ 1正会員 大阪市水道局工務部（ $\bar{\top}$ 559-8558 大阪市住之江区南港北 1-14-16） \\ E-mail: tak-tanaka@suido.city.osaka.jp \\ 2 学生会員 京都大学大学院 工学研究科都市社会工学専攻（率 615-8540 京都市西京区京都大学桂) \\ E-mail: fujimori.yuji@student.mbox.media.kyoto-u.ac.jp \\ 3 正会員 大阪大学特任講師 大学院工学研究科グローバル若手研究者フロンティア研究拠点（テ 565-0871 吹田市山田丘 2-1） \\ E-mail: kaito@ga.eng.osaka-u.ac.jp \\ 4フェロー会員 京都大学教授 経営管理大学院経営管理講座（＝ $606-8501$ 京都市左京区吉田本町） \\ E-mail: kkoba@psa.mbox.media.kyoto-u.ac.jp

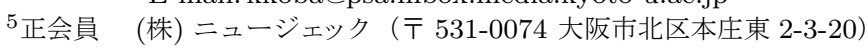 \\ E-mail: yasunotk@newjec.co.jp
}

\begin{abstract}
浄水場施設のアセットマネジメントにおいて，コンクリート版に対する維持管理が重要な課題となっている. 短・中期間を対象とした中性化速度式では，中性化深さが経過年数の平方根に比例するという仮定（以下，「ルー 卜 $t$ 則」と略す）が採用されている。しかし，アセットマネジメントの対象となる長期間に及ぶ中性化過程に関 しては十分な知見が蓄積されていない. 本研究では, 浄水場施設のコンクリート構造物を対象に, 長期にわたっ て蓄積された中性化深さの測定データに基づいて, 長期的な中性化過程を解析するための加速劣化八ザードモ デルを提案する. さらに，ルート $t$ 則に関する統計的仮説検定の結果，少なくとも対象とした長期間のデータに 関してルート $t$ 則は棄却され，現実の中性化過程はルート $t$ 則より，加速して進行することが判明した.
\end{abstract}

Key Words : concrete carbonation, accelerated hazard model, root-t formula, water treatment facility

\section{1. はじめに}

近年，浄水場施設の老朽化が進み，補修時期や更新 時期の精査が大きな問題となっている1). 浄水場施設の 劣化・損傷のモニタリングは, 多大な費用と時間を要 することから，構造物の劣化予測に必要となる点検結 果が十分に蓄積されていないのが実情である。しかし， 近年のアセットマネジメントの重要性に対する認識の 結果, 限られた情報ではあるが, 浄水場施設の劣化過 程に関する点検データもいくつか利用可能になってき ている。このような現実のデータを用いて，これまで 実務において用いられてきた劣化予測式の現象再現性 について実証的な検証を試みることが可能となった。

本研究では，浄水場施設におけるコンクリート構造 物の老朽化の主要な要因の 1 つである中性化過程 ${ }^{1)-4)}$ に着目する.コンクリートの短・中期間を対象とした中 性化予測では, 中性化深さが経過時間の平方根に比例 することが定説（以下,「ルート $t$ 則」と略す）であり， ルート $t$ 則に基づく中性化速度式5)を用いて構造物の設 計が行われている。ルート $t$ 則は，定常状態における炭 酸イオンのコンクリート内拡散現象に基づいて導出さ れた力学モデルであり, 実験室内での自然暴露試験や 促進試験, あるいは数ヶ月から 15 年程度の短・中期的
な現場観測の結果により，その妥当性が確認されてき た5)-24). しかし，アセットマネジメントの対象となる 長期間を対象とした中性化過程に関しては十分な知見 が蓄積されていないのが実情である。とりわけ，長期 間を対象としたアセットマネジメントにおいて，ルー 卜 $t$ 則による劣化予測結果に基づいたライフサイクル 費用評価が経験的妥当性を有しているかどうかを検討 することが必要である。

本研究では，現実に観測された中性化深さの測定デー タに基づいて，コンクリート構造物の中性化速度式を 統計的に推計する方法を提案する. 既往の中性化速度 式5)は確定的モデルであり, 現実のデータとの整合性に 関して，統計的検証が不可能であるという問題がある. そこで，ルート $t$ 則に基づく中性化速度式に対して，1) 加速度パラメータ值（ルート $t$ 則の場合， 0.5 となる） に関する制約を緩和する，2) 中性化過程に介在する個 別的な環境要因を表現する確率誤差項を付加すること により, 統計分析が可能な確率モデル（以下，加速劣 化ハザードモデルと呼ぶ）として再定式化する．以上 のように定式化した加速劣化ハザードモデルは，既往 の中性化速度式を特殊ケースとして包含するような統 計的劣化予測モデルであり，このモデルを推計するこ とにより既往の中性化速度式の現象再現性に関して統 
計的解析を実施することが可能となる.

以上の問題意識の下，本研究では，浄水場施設にお けるコンクリート構造物の中性化判定結果に基づいて, 加速劣化ハザードモデルを推計するとともに，ルート $t$ 則に基づく中性化速度式（力学的劣化モデル）の現象 再現性について実証的に考察する.さらに，加速劣化 ハザードモデルを用いて, 浄水場施設のコンクリート に対するリスクマネジメント指標の設定および余寿命 の評価に関する手法を提案する. 以下, 2. では, 本研 究の基本的な考え方を述べる. 3. で加速劣化ハザード モデルと，それを用いた余寿命の推計方法について言 及する.4. では適用事例について述べる。

\section{2. 本研究の基本的な考え方}

\section{(1) 既往研究の概要}

中性化は, 長年の供用に伴って, 通常高いアルカリ 性を示すコンクリート内に大気中の炭酸ガスが拡散し, 水酸化カルシウムと反応して炭酸カルシウムを生成す ることにより，コンクリートの $\mathrm{pH}$ を低下させる現象 である ${ }^{9)}$. 中性化そのものにより，コンクリートの物理 的, 機能的劣化が発生するわけではない. しかし, 中 性化が鉄筋の位置まで進行すれば，鉄筋の腐食に対す る保護性能を失って，鉄筋腐食の原因となる。また，発 錆による鉄筋の体積膨張がコンクリートのひび割れや かぶりコンクリートのかい離を生じさせ，コンクリー 卜構造物の耐久性を低下させる25).

コンクリート構造物の中性化過程に関しては，実験 的および解析的手法により多くの研究が蓄積されてい る. 実験的研究としては, 自然暴露試験や促進試験等 を通じて, 中性化の進行速度に関する研究が行われて いる.さらに，中性化深さと経過期間の関係を求めた 中性化速度式5)-16) が提案されている。 中でも，岸谷は 建築物の調査データに基づいて, 中性化深さが経過時 間の平方根に比例することを指摘し, コンクリート構 造物の中性化速度式を提案している5). 一方, 解析的研 究として, 物理化学的あるいは熱力学的手法に基づい て，コンクリートの $\mathrm{pH}$ 変化等の予測を行った事例が ある17)-24)。コンクリートは, 当初は $\mathrm{pH} 13$ 程度のア ルカリ性を呈しているが, 大気中に存在する炭酸ガス, 水中に存在する炭酸イオン, その他の酸, 塩などの作 用により，セメント水和物のアルカリ性が中性化して いく. 大気中の炭酸ガスによるコンクリート表面から の中性化の進行が，定常状態における炭酸ガスのコン クリート中への拡散によって生じると仮定すれば, 中 性化深さが経過時間の平方根に比例するという理論式 を導出することができる.すなわち, 中性化深さ $x$ は,
経過時間 $t$ の関数として

$$
x=A \sqrt{t}
$$

と表される。係数 $A$ は，中性化速度係数とも呼ばれ， $A$ の值が大きいほど中性化速度が大きいことを表してい る. 多くの外的 - 内的要因が中性化速度係数 $A$ に影響 を及ぼす。既存コンクリート構造物の調査, 供試体の暴 露試験や促進中性化試験等を通じて, 係数 $A$ に関して 種々の提案5)-16) がなされている. このように, 中性化 深さが経過時間の平方根に比例するという仮定は, 定 常状態における拡散現象に基づいて導出されたもので あり，モデル化の前提となる諸条件を満足する範囲にお いて, 理論的な妥当性が保証される。したがって, 実験 的および解析的研究のいずれにおいても, 中性化は一 般的にルート $t$ 則に従って進行すると考えられており, 実務レベルの研究はルート $t$ 則を基本式としながらも, 中性化速度係数にどのような要因を考慮す心゙きかを検 討することによって発展してきた経緯がある10),11)。実 際に, ルート $t$ 則を用いた中性化速度式は実用的であ り，設計段階においてコンクリート構造物のかぶり厚 等を決定する拠り所となっている.

その一方で，コンクリートは鋼材とは異なり，材料・ 施工の質を均一化することは難しい. また, コンクリー 卜構造物の劣化過程は環境依存性が強いことも指摘さ れている26),27). 例えば土木学会コンクリート標準示方 書28)には,「中性化の進行速度は, コンクリート中にお ける二酸化炭素の移動速度と細孔溶液の $\mathrm{pH}$ 保持能力 によって決まる。二酸化炭素の移動速度は, セメント 硬化体および骨材の空隙量と空隙構造に影響を受ける. このため, セメント・混和剤・骨材の種類, 水セメント 比（水結合材比）, 結合材の水和度などが問題となる. (中略) したがっていずれにしても, 中性化速度はコン クリートの含水状態の影響を受けることになり，考慮 すべき環境条件として, 温度・湿度・降雨頻度・日射等 があげられる。一方, 細孔溶液の $\mathrm{pH}$ 保持能力は, 水酸 化カルシウム量で決まる。このため, セメント・混和剤 の種類, 水セメント比, 単位セメント量, 結合材の水 和度等の影響を受ける。以上のことから，これらの影 響を適切に評価して，予測に取り込む必要がある.」と の記述があり, 中性化過程には多種多様な要因が介在 していることが理解できる。しかし現実的には，実務 レベルでこれらの要因を取捨選択することは困難であ り，同標準においても，中性化深さの測定值を用いて 中性化速度係数を逆算することで, その後の予測に反 映させることを提案している28).ただし，そのような 場合であっても中性化深さの測定結果は, 同一構造物, 部材においても空間的なばらつきが大きいことが指摘 されている29),30). したがって, 確定的なモデルによっ て中性化過程を記述し, その結果をアセットマネジメ 
ントに反映させることには限界がある。不確実性を考 慮したような確率モデルを用いて中性化過程を記述し， 中性化過程に影響を及ぼす要因を統計的に検証するこ とが重要である，ただし，測定データから中性化過程 を記述するモデルを構築するには膨大なデータを必要 とすることから，ルート $t$ 則に基づく予測式を包括し たようなベースラインを設定し, 測定データにより統 計的に推計することが効率的である. したがって, こ れ以降で述べるモデルと方法論は確率モデルを採用す る等の拡張はあるものの, 従来の予測式と方法論を踏 襲し，その延長線上に位置していることを断っておく.

\section{（2） アセットマネジメントと劣化予測式}

コンクリート構造物の維持補修計画を検討する場合, 長期にわたる計画期間を対象として，ライフサイクル 費用の最小化に資するような最適補修計画を立案する ことが主たる目的となる ${ }^{25)}$. アセットマネジメントに おいて,ルート $t$ 則に基づいた中性化速度式を用いた 場合，ライフサイクル費用分析においていくつかの評 価上の問題が発生する.ルート $t$ 則に基づいた中性化 速度式は, ライフサイクルの後半において劣化速度が 非常に緩慢になることを意味する，その結果，最適な 更新間隔を算定しても, 非現実的な結果が得られる場 合も少なくない，ライフサイクル後半期において，定 常状態における炭酸イオンの拡散現象以外の原因によ り, 中性化が進展している場合には, ルート $t$ 則に基づ いた中性化予測を用いることにより対策時期の判断に 重大な遅延をもたらす可能性がある.さらに，のちに 図-1に示すように，中性化速度式のわずかな推計誤差 が補修タイミングの決定に多大な誤差をもたらすこと になる。しかしながら，これは既往研究が中性化機構 の解明や中性化の誘因・促進要因を特定化することを 主たる目的としているのに対して，アセットマネジメ ントが補修や更新時期の決定を主たる目的としている ことが原因である.2.(1) で述べたように中性化過程に 影響を及ぼす要因は多種多様であり, 機構解明のため に記述されたモデルで長期間の劣化予測を行うことや, 包括した予測式を定式化することはそもそも現実的で はない. 目的（本研究では長期間の中性化予測を行う） に応じた方法論の開発が不可欠である.

既往研究では, 数ヶ月から 15 年程度の短・中期間を 対象とした室内実験や現況調查により中性化速度式を 検証しており，アセットマネジメントが対象とするよ うな長期間を対象として中性化速度を検討した事例は, 筆者らの知る限り存在しない. 実際の使用環境で, 長 期間にわたり供用しているコンクリート構造物の中性 化過程に関しては，ほとんど情報が蓄積されていない のが実情である、対策時期に関する判断遅延リスクを
避けるためには, 現実のコンクリートの中性化過程に 関する実データに基づいて, 中性化速度式を統計的に 推計することが必要となる。本研究では, 1. で言及し たように，既往研究における中性化速度式に対して，1) 中性化方程式における加速度パラメータ值の制約を緩 和寸る，2）中性化過程に介在する個別的な環境要因を 表現する確率誤差項を付加したような加速劣化ハザー ドモデルを提案する. 加速劣化ハザードモデルの加速 度パラメータを 0.5 に拘束したモデルは, ルート $t$ 則に 基づく中性化速度式に確率誤差項を付加した力学モデ ルに相当する. したがって, 加速劣化八ザードモデル を用いて, 中性化速度式におけるルート $t$ 則に関寸る 統計的検定を行うことが可能となる.

当然のことながら, 本研究で提案する加速劣化ハザー ドモデルは, 確率誤差項の確率分布として, パラメト リックな確率分布関数を想定しており, 仮説検定の結果 が確率誤差項分布に関する特定化誤差の影響を受けて いる可能性がある.このため, 加速劣化八ザードモデ ルを用いた仮説検定によりルート $t$ 則に関する仮説が棄 却されたからといって, 直ちに中性化に関わるルート $t$ 則の妥当性が否定されるわけではない.しかし, 今後, 点検サンプルを蓄積することにより, ルート $t$ 則の経験 的有効性に関する研究を積み重ねることが重要である.

\section{（3）ベースラインモデルと比例性}

目視点検の結果に基づいて, 構造物の劣化過程を予 測する統計的劣化予測モデルに関しては, 多くの研究 蓄積31)-35)がある. 統計的劣化モデルを推計するため には，一定量のデータの蓄積が必要である。たとえば, 津田ら ${ }^{33)}$ はマルコフ劣化モデルを安定的に推計するた めには, 2,000 個程度の点検データが必要となるとして いる. 統計的予測モデルは, 劣化過程のベンチマーク となる力学モデルを内蔵していないため, 劣化過程を 安定的に表現するために, 大量のデータが必要となる. これに対して, 力学的劣化モデルは, 劣化過程を直接 モデル化しているため, (モデル化が正しい限り) より 少ないデータを用いて劣化予測を行うことが可能とな る. しかし, 現実の劣化過程には多様な要因が介在す るため, 単一の力学モデルを用いて劣化過程を表現す るには限界がある。このため, 限られたデータを用い て力学モデルを統計的に推計しようとするハイブリッ ド型劣化予測モデル36)も提案されている.

本研究では, 比例八ザードモデル37)を用いたハイブ リッド型劣化予測モデルを提案する. 比例ハザードモ デルは, ベースラインの寿命関数（ベースラインモデ ル）を特定化し，定数や八ザード形状パラメータを最尤 法により推計する手法である，比例ハザードモデルは, 構造物による劣化速度の異質性を表現するが，構造物 


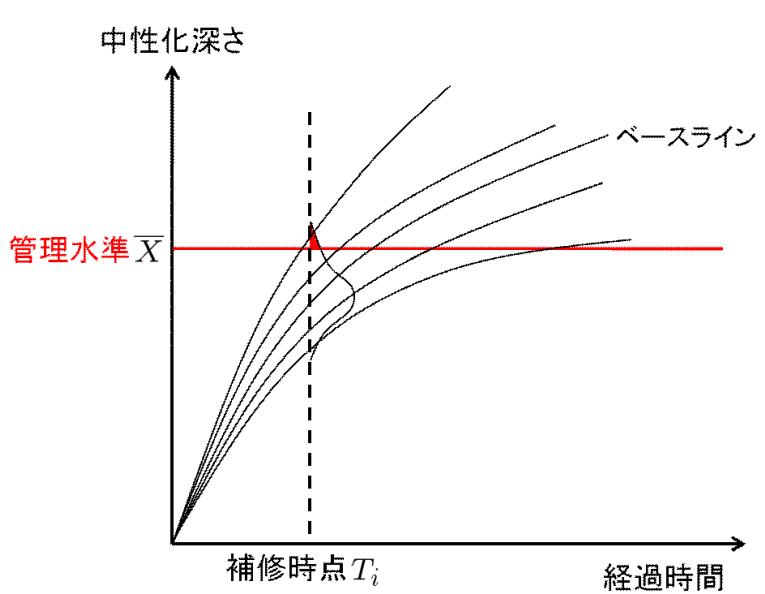

注）中性化曲線と管理水準 $\bar{X}$ の交点が補修タイミングとな る.これらの交点の分布より, 中性化曲線のわずかなシフ トが補修タイミングの大きな変動をもたらすことが理解で きる。また， ある補修時点における中性化深さの確率分布 も示しているが，中性化が管理水準以上に進展する超過確 率は図中の斜線部分の面積で表される.

図-1 ルート $t$ 則に基づく中性化曲線

ごとに定義された損傷発生ハザード関数が交差しない ことを仮定する。ルート $t$ 則を用いた中性化速度式 (1) も，このような比例性を満足している．才なわち， ベー スラインモデルとしてパラメトリックな関数 $x=\sqrt{t}$ を 用いるとともに，構造物ごとの中性化速度の異質性を 中性化速度係数 $A$ により表現している. 比例ハザード モデルは，ベースラインモデルを特定化することによ り，パラメータ空間が相対的に絞られるため, 限定さ れたデータによっても推計できる点に利点がある.

本研究で提案する加速劣化ハザードモデルは, 比例 ハザードモデルの性質を満足している. その際, ベー スラインモデルとして, 加速度方程式 (ベースライン 劣化速度式） $x=t^{1 / \alpha}$ を採用する. ここに, $x$ は中性化 深さであり, 経過時間 $t$ の関数として表現される. $\alpha$ は 加速度パラメータであり, ルート $t$ 則に基づく中性化速 度式 (1) は, 加速度パラメータを $\alpha=2$ に設定したこ とに他ならない.さらに, 加速劣化ハザードモデルは, ベースラインの中性化速度式として加速度方程式を採 用し, 中性化係数に確率誤差項を導入することにより, 個別構造物の中性化速度の異質性を表現しようとする 点に特徵がある。

\section{(4) 浄水場施設のリスクマネジメント}

図-1 は, 加速劣化ハザードモデルを用いて作成した 中性化の進行プロセス（中性化曲線）を表現している. 同図の縦軸は中性化深さを，横軸は経過時間を表して いる.コンクリート構造物特性や使用環境が同一でも， 施工条件や個別的要因等の異質性により, 中性化曲線 が多様に異なる.この図では, ベースラインモデルと
してルート $t$ 則を採用している. 縦軸に中性化深さに 関する管理水準 $\bar{X}$ を決定し, 横軸と平行に予防的に補 修すべき限界ライン (図中の赤線) を定めると, それと 中性化曲線との交点から, 補修時期を決定することが できる. 限界ラインの例として, RC コンクリート構造 物の場合，鉄筋位置までのかぶり厚さを管理限界ライ ンとすると, 中性化曲線と管理限界ラインの交点より, 補修時期の設定に資する情報が得られる.ルート $t$ 則に 基づく中性化曲線は, 図-1に示すように凹曲線として 表現される.このため, 中性化曲線のわずかな推計誤 差が，補修時期の大きな変動に結びつく可能性がある. 現実のコンクリート構造物の中性化進行過程には, 多 大な不確実性が存在するため, 補修時期を確定的に決 定することができない. しかし, 構造物個々の中性化曲 線の多様性を支配する複数の要因を異質性パラメータ として 1 つの変数に集約化し，さらにその異質性パラ メータが形成する分布を推計できれば，補修時期タイ ミングの確率分布を同図のように導出することができ る. その上で, 現実の中性化が管理水準以上に進展す る超過確率（図中の赤色部分の面積）を設定すれば，補 修時期を決定することが可能となる. このように加速 劣化ハザードモデルは, 個別構造物の中性化進行に関 する異質性をモデル化することが可能となるため, ア セットマネジメントを実施するうえで必要なリスクマ ネジメント指標を導出することが可能となる.このよ うなリスクマネジメント指標に関しては，3.(4) で言及 する.

\section{3. 加速劣化ハザードモデル}

\section{（1）劣化ハザードモデル}

中性化過程には多種多様な要因が介在し, 中性化速度 係数に各種要因が及ぼす影響について実証的に検討が なされ，適宜中性化速度係数に反映されてきた ${ }^{5)-16)}$. しかし，その中には計測が極めて困難な要因，未だ特 定化されていない要因などが含まれており, 中性化過 程に及ぼす影響は大きいものの, データが蓄積されて いないケースも少なくない。このような場合にこれま では, 理論的妥当性が保証されたルート $t$ 則に基づき, 測定データを用いて中性化速度係数を逆算する, すな わち中性化速度係数に全ての要因の影響を集約させる という方法論が採用されてきた. 本研究においても, 既 往の方法論を踏襲する形で, 中性化過程を加速劣化八 ザードモデルで表現し, 測定データにより確率モデル を統計的に推計する方法論を提案する.さらに，中性 化速度係数に加えて, 加速度パラメータ值も未知パラ メータと考える. 実測データとの適合性を高めること で，長期間の中性化予測精度の向上を図る. 
いま，対象とするコンクリート構造物群が， $n$ 個の部 材で構成されていると考える. 対象とする部材 $i(i=$ $1, \cdots, n)$ の前回の更新時点からの経過時間を $t_{i}$, コン クリート部材の中性化深さを $x_{i}(\mathrm{~mm})$ と表す. 中性化 の進行プロセスを

$$
\begin{aligned}
& x_{i}=\exp \left(\frac{-B_{i}}{\alpha}\right) t_{i}^{1 / \alpha} \\
& B_{i}=\boldsymbol{\theta}^{\prime} \boldsymbol{z}_{i}+\sigma w_{i} \\
& (i=1, \cdots, n)
\end{aligned}
$$

と定式化する。ここで， $\alpha(>0)$ は加速度パラメータ， $B_{i}$ は，個々のコンクリート部材の構造特性の異質性を反映 する係数（中性化係数と呼ぶ）であり，加速要因と誤差 項の和で構成される.ただし, $\boldsymbol{z}_{i}=\left(1, z_{i}^{1}, \cdots, z_{i}^{M}\right)$ は部 材 $i$ の劣化・損傷の共変量ベクトル, $\boldsymbol{\theta}=\left(\theta_{0}, \theta_{1}, \cdots, \theta_{M}\right)$ は丰命に関するパラメータベクトル， $\theta_{0}$ は定数パラメー 夕, $w_{i}$ は部材 $i$ に固有な劣化要因を表す確率誤差項, $\sigma$ は偏差パラメータを表す。ここで， $\alpha=2$ を仮定すれば

$$
x_{i}=\exp \left(\frac{-B_{i}}{2}\right) t_{i}^{1 / 2}
$$

を得る. 式 (3) は中性化深さが経過時間の平方根に比例 する既往の中性化速度式に他ならない, すなわち, 式 (3) は，既往の中性化速度式を特殊ケースとして内包す るモデルとなっている. 右辺の中性化係数 $B_{i}$ は, 個々 のコンクリート構造物の中性化速度が, 構造特性 $\boldsymbol{z}_{i}$ と 誤差項 $w_{i}$ に応じて異質であることを表現している.

加速劣化ハザードモデル15)では，劣化状態がある管 理水準に到達するまでの経過時間（寿命）の対数值を, 劣化・損傷の共変量 $\boldsymbol{\theta}^{\prime} \boldsymbol{z}_{i}$ と誤差項 $\sigma w_{i}$ の線形和として 表現する. 式 $(2 \mathrm{a})$ の両辺の対数をとれば, 加速劣化八 ザードモデル

$$
y_{i}=\ln t_{i}=\alpha \ln x_{i}+\boldsymbol{\theta}^{\prime} \boldsymbol{z}_{i}+\sigma w_{i}(i=1, \cdots, n)(4)
$$

を得る. 確率変動項 $w_{i}$ が確率密度関数

$$
f_{w}\left(w_{i}\right)=\exp \left\{-w_{i}-\exp \left(-w_{i}\right)\right\}
$$

で表現される標準ガンベル分布に従うと仮定する。た だし, $E\left(w_{i}\right)=\gamma$ であり, $\gamma(=0.57722 \cdots)$ はオイラー 定数である. 式 (4) を

$$
w_{i}=\frac{y_{i}-\alpha \ln x_{i}-\boldsymbol{\theta}^{\prime} \boldsymbol{z}_{i}}{\sigma}(i=1, \cdots, n)
$$

と書き直し, 確率密度関数 (5) の変数変換を行う。 その 結果, 部材 $i$ が構造特性 $\boldsymbol{z}_{i}$ において中性化深さが管理 水準 $x_{i}$ に到達するまでの所要時間（寿命）の条件付分 布を表す確率密度関数は,

$$
\begin{aligned}
& f_{y}\left(y_{i} \mid x_{i}, \boldsymbol{z}_{i}\right)=\frac{1}{\sigma} f_{w}\left(\frac{y_{i}-\alpha \ln x_{i}-\boldsymbol{\theta}^{\prime} \boldsymbol{z}_{i}}{\sigma}\right) \\
& =\frac{1}{\sigma} \exp \left\{-\exp \left(-\frac{y_{i}-\alpha \ln x_{i}-\boldsymbol{\theta}^{\prime} \boldsymbol{z}_{i}}{\sigma}\right)\right. \\
& \left.-\frac{y_{i}-\alpha \ln x_{i}-\boldsymbol{\theta}^{\prime} \boldsymbol{z}_{i}}{\sigma}\right\}
\end{aligned}
$$

と表すことができる. 一方, 確率密度関数 (5)より, 生 存関数は

$$
\begin{aligned}
S_{w}\left(w_{i}\right) & =1-\int_{-\infty}^{w_{i}} f_{w}(w) d w \\
& =1-\exp \left\{-\exp \left(-w_{i}\right)\right\}
\end{aligned}
$$

と表現される. 部材 $i$ が構造特性 $\boldsymbol{z}_{i}$ において対数時間 $y_{i}$ が経過した時点で, 中性化深さが管理水準 $x_{i}$ まで到 達していない確率は, 生存関数

$$
\begin{aligned}
& S_{y}\left(y_{i} \mid x_{i}, \boldsymbol{z}_{i}\right)=S_{w}\left(\frac{y_{i}-\alpha \ln x_{i}-\boldsymbol{\theta}^{\prime} \boldsymbol{z}_{i}}{\sigma}\right) \\
& =1-\exp \left\{-\exp \left(-\frac{y_{i}-\alpha \ln x_{i}-\boldsymbol{\theta}^{\prime} \boldsymbol{z}_{i}}{\sigma}\right)\right\}
\end{aligned}
$$

を用いて表現できる. さらに, 変数変換 $t_{i}=\exp \left(y_{i}\right)$ に より経過時間 $t_{i}$ に関する生存関数は,

$$
\begin{aligned}
& S_{t}\left(t_{i} \mid x_{i}, \boldsymbol{z}_{i}\right)=1-\exp \left\{-\lambda_{i}\left(x_{i}, \boldsymbol{z}_{i}\right) t_{i}^{-\beta}\right\} \\
& \lambda_{i}\left(x_{i}, \boldsymbol{z}_{i}\right)=\exp \left(\frac{\alpha \ln x_{i}+\boldsymbol{\theta}^{\prime} \boldsymbol{z}_{i}}{\sigma}\right)
\end{aligned}
$$

となる.ただし， $\beta=1 / \sigma$ である.

このように, 加速劣化ハザードモデルに対しても, 生 存関数 $(10 \mathrm{a})$ を導出することができる. 伝統的なハザー ドモデル38)-41) は, 対象物の寿命が確率分布すると仮 定しているのに対して，加速劣化八ザードモデルでは， 個別部材の中性化速度係数の異質性が寿命分布の原因 となっていることに留意する必要がある。 また, 生存 関数は, 中性化の進展が所与の中性化深さ $x_{i}$ に到達す るまでの経過時間の分布を示しており, 個々の部材に おける中性化プロセスを示したものではない. 当然の ことながら, 確率変動項 $w_{i}$ の確率分布として, ガンベ ル関数以外の確率分布 (例えば, 対数正規分布, ロジ ステイック分布等）を採用することも可能である.この うち, 対数正規分布, ロジスティック分布は，ある時期 にハザード率のピークがあるようなハンプ型形状の場 合に適している ${ }^{42)}$. しかし, 対象とする水道施設の場 合，のちに考察するように，経過時間とともに劣化が 加速しハザード率が増加するような劣化特性を有して いる．さらに，ガンベル分布は，ハザード率が経過時 間に対して一定, 逢増, 逢減となるような変化過程を 表現できるという柔軟な構造を有している. 以上の理 由により, 本研究では確率誤差変動としてガンベル分 布を採用することとする.

\section{(2) ハザード関数の推計}

コンクリート構造物の中性化過程に関するサンプル の利用可能性により, ハザード関数の推計方法が異な る. 本研究では, 以下の 2 つ異なったタイプのサンプ ルが入手可能な場合を考える. すなわち，1) 経過時間 $y_{i}$ と中性化深さ $x_{i}$ に関する情報が獲得可能な場合 (タ イプ 1)，2）中性化深さが管理水準 $x_{i}$ に到達したかど 
うかを表すデータのみが入手可能な場合 (タイプ 2) と いう 2 種類の場合を考える. タイプ 1 は非破壊検查な ど詳細な検查を実施した場合, タイプ 2 は目視点検な どを実施した場合を想定している.

\section{a) タイプ1の場合}

本研究の適用事例では, 浄水施設の更新時に, コン クリート版から無作為にサンプルコアを抽出し, 各サ ンプルの中性深さを実測している。経過時間の異なる 施設からサンプルを抽出しており, 各サンプルの情報 を $\boldsymbol{\xi}_{i}(i=1, \cdots, n)$ を $\boldsymbol{\xi}_{i}=\left(x_{i}, y_{i}, \boldsymbol{z}_{i}\right)$ と表すことがで きる.ただし， $\boldsymbol{z}_{i}=\left(z_{i}^{1}, \cdots, z_{i}^{M}\right)$ はサンプル $i$ の構造 特性を表す心゙クトルであり, $z_{i}^{m}(m=1, \cdots, M)$ はサ ンプル $i$ の $m$ 番目の構造特性を表している. サンプル $\boldsymbol{\xi}_{i}$ が観測される尤度 $\mathcal{L}_{i}$ は,

$$
\mathcal{L}_{i}=\frac{1}{\sigma} f_{w}\left(\frac{y_{i}-\alpha \ln x_{i}-\boldsymbol{\theta}^{\prime} \boldsymbol{z}_{i}}{\sigma}\right)
$$

と表すことができる．ここで，浄水場施設の布設年次は 同一であるとは限らず，異なる場合を含む. 浄水場施設 は, 構造物の諸元や環境条件が均質でない場合が多い. 対象と寸る 単位の浄水場施設は, それらの劣化・損傷 に関して相互に独立であると仮定できる。したがって, すべてのサンプル $\boldsymbol{\xi}=\left\{\boldsymbol{\xi}_{i}(i=1, \cdots, n)\right\}$ を与件とし た対数尤度関数は

$$
\begin{aligned}
& \ln \mathcal{L}(\alpha, \boldsymbol{\theta}, \sigma) \\
& \quad=\sum_{i=1}^{n}\left\{-\exp \left(-\frac{y_{i}-\alpha \ln x_{i}-\boldsymbol{\theta}^{\prime} \boldsymbol{z}_{i}}{\sigma}\right)\right. \\
& \left.\quad-\left(\frac{y_{i}-\alpha \ln x_{i}-\boldsymbol{\theta}^{\prime} \boldsymbol{z}_{i}}{\sigma}\right)\right\}-n \ln \sigma
\end{aligned}
$$

と表される. タイプ 1 のデータは, 加速劣化ハザード モデルの説明変数に関する情報が直接観測可能である 場合を想定している。このようなデータは，適用事例 のように施設更新が実施された機会等を利用して，コ ンクリートのコアサンプルを抽出することが必要とな る. しかし, 現在供用中の浄水施設に対して, このよ うなコアサンプルを把握することは容易ではない．

\section{b) タイプ 2 の場合}

目視点検で, 中性化により構造物が限界状態に達成 しているかどうかを判定することができる場合を考え る、さらに，非破壊試験等により，コンクリートの鉄 筋かぶり厚 $x_{i}$ が測定できると考える. 目視点検で, 構 造物に中性化による損傷・損壊が発見された場合, 中 性化深さが少なくともかぶり深さ $x_{i}$ に到達していると 考えよう。この場合, 目視点検のサンプルが有する情 報は $\boldsymbol{\xi}_{i}=\left(\delta_{i}, y_{i}, \boldsymbol{z}_{i}\right)$ として整理できる.ただし， $\delta_{i}$ は ダミー変数であり,

$$
\delta_{i}= \begin{cases}1 & \text { 管理水準を満足しない場合 } \\ 0 & \text { 満足する場合 }\end{cases}
$$

と定義する．すなわち， $\delta_{i}=1$ ならば，構造物 $i$ に中 性化による損傷 - 損壊が発生し, 中性化が鉄筋の位置 まで進行していることを意味している． $\delta_{i}=1$ が生起 する確率は, 寿命関数

$$
\begin{aligned}
& F_{y}\left(y_{i} \mid x_{i}, \boldsymbol{z}_{i}\right)=1-S_{y}\left(y_{i} \mid x_{i}, \boldsymbol{z}_{i}\right) \\
& =\exp \left\{-\exp \left(-\frac{y_{i}-\alpha \ln x_{i}-\boldsymbol{\theta}^{\prime} \boldsymbol{z}_{i}}{\sigma}\right)\right\}
\end{aligned}
$$

を用いて表現される，一方， $\delta_{i}=0$ ならば，管理水準 を満足しており，その確率は生存確率 (10a) を用いて 表現される. 浄水場施設をある経過時間 $y_{i}=\ln t_{i}$ に点 検すると,「すでに，ある限界状態に到達している」か， あるいは「未到達であるか」のいずれかの状態が観測 される。したがって, 尤度関数は

$$
\begin{aligned}
& \mathcal{L}(\alpha, \boldsymbol{\theta}, \sigma) \\
& =\prod_{i=1}^{n}\left\{F_{y}\left(y_{i} \mid x_{i}, \boldsymbol{z}_{i}\right)\right\}^{\delta_{i}}\left\{S_{y}\left(y_{i} \mid x_{i}, \boldsymbol{z}_{i}\right)\right\}^{1-\delta_{i}}
\end{aligned}
$$

と表せる.ささら，対数尤度関数は次式で表される.

$$
\begin{aligned}
\ln \mathcal{L}(\alpha, \boldsymbol{\theta}, \sigma) & =\sum_{i=1}^{n} \delta_{i} A_{i} \\
& +\sum_{i=1}^{n}\left(1-\delta_{i}\right) \ln \left\{1-\exp \left(A_{i}\right)\right\}
\end{aligned}
$$

ここで, $A_{i}=-\exp \left\{-\left(y_{i}-\alpha \ln x_{i}-\boldsymbol{\theta}^{\prime} \boldsymbol{z}_{i}\right) / \sigma\right\}$ である. なお，多くのコンクリート構造物の場合，タイプ 1 の データを入手寸ることが困難であり, タイプ 2 のデー 夕のみが入手可能な場合が少なくない。 しかし, 浄水 場施設は, 高度なコンクリート管理が必要であり, タイ プ 2 のようにコンクリートの中性化が限界状態に到達 していることはありえない.したがって, タイプ1の データに頼らざるを得ず，このことが浄水場施設の劣 化状態に関寸る情報の蓄積が十分でないことの原因と なっている. 本研究の適用事例は, 浄水場のコンクリー 卜構造物に関する詳細調査が蓄積されており, タイプ 1 のデータが入手可能な場合をとりあげる.

\section{c) 最尤推計問題}

パラメータの最尤推計問題は, いずれのタイプのデー 夕を用いた場合も, 対数尤度関数最大化問題

$$
\max _{\alpha, \boldsymbol{\theta}, \sigma}\{\ln \mathcal{L}(\alpha, \boldsymbol{\theta}, \sigma)\}
$$

に帰着する.ここで，パラメータベクトルを $(\boldsymbol{\zeta}, \sigma)=$ $\left(\zeta_{1}, \cdots, \zeta_{M+2}, \sigma\right)=(\alpha, \boldsymbol{\theta}, \sigma)$ と書き換える. 対数尤度 関数 (12) は $\sigma$ に関して凸性が保証されない. したがっ て, $\sigma$ に関数する直接探索法と残りのパラメータに関 するニュートン・ラフソン法40)を組み合わせた方法に よりパラメータ $(\boldsymbol{\zeta}, \sigma)$ に関する最尤推計量を求めるこ ととする.すなおち， $\sigma$ の值を $\bar{\sigma} に$ 固定した場合，残 りのパラメータ $\boldsymbol{\zeta}$ の条件付き最尤推計量 $\boldsymbol{\zeta}^{*}(\bar{\sigma})$ は非線 
形連立方程式

$$
\begin{aligned}
& \frac{\partial \ln \mathcal{L}(\boldsymbol{\zeta}, \bar{\sigma})}{\zeta_{i}}=0 \\
& (i=1, \cdots, M+2)
\end{aligned}
$$

の解として求まる. さらに, 分散パラメータ $\sigma$ の最尤 推計量 $\sigma^{*}$ は, 1 次元探索問題

$$
\max _{\sigma>0}\left\{\mathcal{L}\left(\boldsymbol{\zeta}^{*}(\sigma), \sigma\right)\right\}
$$

を解くことにより得られる。ささに，表記の都合上， 最尤推計量 $\left(\boldsymbol{\zeta}^{*}\left(\sigma^{*}\right), \sigma^{*}\right)$ を $\boldsymbol{\zeta}^{*}=\left(\zeta_{1}^{*}, \cdots, \zeta_{M+3}\right)=$ $\left(\boldsymbol{\zeta}^{*}\left(\sigma^{*}\right), \sigma^{*}\right)$ と書き改めよう. 最尤推計量 $\boldsymbol{\zeta}^{*}$ の近傍で 対数尤度関数が局所的に凸関数である場合, パラメー 夕の漸近的な共分散行列の推計量 $\hat{\boldsymbol{\Sigma}}\left(\boldsymbol{\zeta}^{*}\right)$ は,

$$
\hat{\boldsymbol{\Sigma}}\left(\boldsymbol{\zeta}^{*}\right)=\left[\frac{\partial^{2} \ln \mathcal{L}\left(\boldsymbol{\zeta}^{*}\right)}{\partial \zeta_{i} \partial \zeta_{i^{\prime}}}\right]^{-1}
$$

と表すことができる ${ }^{43), 44)}$ 。ただし, 上式の右辺の逆行 列は $\partial^{2} \ln \mathcal{L}\left(\boldsymbol{\zeta}^{*}\right) / \partial \zeta_{i} \partial \zeta_{i^{\prime}}$ を要素とする $(M+3) \times(M+3)$ 次の Fisher 情報行列 ${ }^{44)}$ の逆行列である. 最尤推計量 $\zeta^{*}$ を求めれば, 共分散行列の推計量 $\hat{\boldsymbol{\Sigma}}\left(\boldsymbol{\zeta}^{*}\right)$ を用いて $t$ - 検 定統計量を推計できる.

\section{(3) ルート $t$ 則の統計的検定}

ルート $t$ 則を用いた中性化速度式は，加速劣化ハザー ドモデルの加速度パラメータを $\alpha=2$ に設定した特殊 ケースに相当する. そこで, 2 種類の加速劣化ハザード モデル

$$
\begin{aligned}
& y_{i}=\alpha_{1} \ln x_{i}+\boldsymbol{\theta}_{1}^{\prime} \boldsymbol{z}_{i}+\sigma_{1} w_{i} \\
& y_{i}=2 \ln x_{i}+\boldsymbol{\theta}_{2}^{\prime} \boldsymbol{z}_{i}+\sigma_{2} w_{i}
\end{aligned}
$$

を考える.さらに, これら 2 種類の加速劣化ハザード モデル $(22 \mathrm{a}),(22 \mathrm{~b})$ のパラメータの最尤推計量を, それ ぞれ $\left(\hat{\alpha}_{1}, \hat{\boldsymbol{\theta}}_{1}, \hat{\sigma}_{1}\right),\left(2, \hat{\boldsymbol{\theta}}_{2}, \hat{\sigma}_{2}\right)$ と表そう。ルート $t$ 則に関 する仮説検定モデルは

$$
\begin{cases}H_{0} & \hat{\alpha}_{1}=2 \\ H_{1} & \hat{\alpha}_{1} \neq 2\end{cases}
$$

と定式化できる. すなわち, 帰無仮説 $H_{0}$ を対立仮説 $H_{1}$ に対して検定する問題を考える.ここで, 尤度比検 定法を用いれば，仮説検定統計量 $\xi$ は

$$
\xi=2\left\{\mathcal{L}\left(\hat{\alpha}_{1}, \hat{\boldsymbol{\theta}}_{1}, \hat{\sigma}_{1}\right)-\mathcal{L}\left(2, \hat{\boldsymbol{\theta}}_{2}, \hat{\sigma}_{2}\right)\right\}
$$

と定式化される.ただし, $\mathcal{L}\left(\hat{\alpha}_{1}, \hat{\boldsymbol{\theta}}_{1}, \hat{\sigma}_{1}\right), \mathcal{L}\left(2, \hat{\boldsymbol{\theta}}_{2}, \hat{\sigma}_{2}\right)$ は, それぞれ最尤推計量 $\left(\hat{\alpha}_{1}, \hat{\boldsymbol{\theta}}_{1}, \hat{\sigma}_{1}\right),\left(2, \hat{\boldsymbol{\theta}}_{2}, \hat{\sigma}_{2}\right)$ に対して定 義される尤度である. この時, 検定統計量 $\xi$ が棄却域 $\xi \geq \chi_{(100-\alpha)}^{2}(\gamma)$ に入ば有意水準 $\alpha \%$ で帚無仮説 $H_{0}$ を 棄却できる. ここに, $\chi_{(100-\alpha)}^{2}(\gamma)$ は, 自由度 $\gamma=M+2$ の $\chi^{2}$ 分布における有意水準 $\alpha \%$ の臨界值を表す.

\section{（4）リスクマネジメント指標}

コンクリート部材の中性化速度係数に異質性が存在 するため, 部材ごとに中性化の進展特性が異なる.した
がって，初期時点からある一定の時間 $T_{i}$ が経過した時 点で, 中性化深さの確率分布を知ることができる.この ように，中性化深さに関するリスク管理指標を「中性 化深さ指標」と呼ぶ. 一方, 加速劣化ハザードモデルを 用いた場合，任意の経過時間に対して，中性化深さが 管理水準 $x_{i}$ まで到達していない確率を生存関数 (10a) を用いて表現できる. 生存関数は中性化が所与の管理 水準 (中性化深さ) まで到達する経過時間分布を表して いる. 生存関数 (10a) を用いて, 中性化が所与の深さ に到達するまでの経過時間に関するリスク管理指標 (余 寿命指標と呼ぶ) を定式化できる. 本研究では, コンク リート部材の劣化特性を表すリスク指標として，1）中 性化深さ指標，2) 余寿命指標をとりあげる.

\section{a) 中性化深さ指標}

初期時点から一定の時間 $T_{i}$ (対数時間 $Y_{i}=\ln T_{i}$ ) が 経過した現時点を考える. この時, 加速劣化ハザード モデル (4)より, 中性化深さ $x_{i}$ は

$$
x_{i}=T_{i}^{1 / \alpha} \exp \left(\frac{-\boldsymbol{\theta}^{\prime} \boldsymbol{z}_{i}-\sigma w_{i}}{\alpha}\right)
$$

と表される。ここで, 確率誤差項 $w_{i}$ が確率密度関数 $f_{w}\left(w_{i}\right)$ (式 $(5)$ 参照) に従うことを考慮すれば, 変数 変換

$$
w_{i}=\frac{-\alpha \ln x_{i}+\ln T_{i}-\boldsymbol{\theta}^{\prime} \boldsymbol{z}_{i}}{\sigma}(i=1, \cdots, n)
$$

により, 経過時間 $T_{i}$ における対数中性化深さ $\iota_{i}=\ln x_{i}$ の条件付分布を表す確率密度関数は,

$$
\begin{aligned}
& f_{\iota}\left(\iota_{i} \mid T_{i}, \boldsymbol{z}_{i}\right)=\frac{\alpha}{\sigma} f_{w}\left(\frac{-\alpha \iota_{i}+\ln T_{i}-\boldsymbol{\theta}^{\prime} \boldsymbol{z}_{i}}{\sigma}\right) \\
& =\frac{\alpha}{\sigma} \exp \left\{-\exp \left(\frac{\alpha \iota_{i}-\ln T_{i}+\boldsymbol{\theta}^{\prime} \boldsymbol{z}_{i}}{\sigma}\right)\right. \\
& \left.-\frac{\alpha \iota_{i}-\ln T_{i}+\boldsymbol{\theta}^{\prime} \boldsymbol{z}_{i}}{\sigma}\right\}
\end{aligned}
$$

と表すことができる.さらに, 変数変換 $x_{i}=\exp \left(\iota_{i}\right)$ より, 経過時間 $T_{i}$ における中性化深さ $x_{i}$ の条件付確 率密度関数は,

$$
\begin{aligned}
f_{x_{i}}\left(x_{i} \mid T_{i}, \boldsymbol{z}_{i}\right) & =\frac{\alpha}{\sigma x_{i}} f_{w}\left(\frac{-\alpha \ln x_{i}+\ln T_{i}-\boldsymbol{\theta}^{\prime} \boldsymbol{z}_{i}}{\sigma}\right) \\
& =\frac{\kappa x_{i}^{\kappa-1}}{\rho_{i}\left(T_{i}\right)} \exp \left(-\frac{x_{i}^{\kappa}}{\rho_{i}\left(T_{i}\right)}\right)
\end{aligned}
$$

と表すことができる.ただし，

$$
\begin{aligned}
& \kappa=\frac{\alpha}{\sigma} \\
& \rho_{i}\left(T_{i}\right)=\left\{\exp \left(\frac{\boldsymbol{\theta}^{\prime} \boldsymbol{z}_{i}-\ln T_{i}}{\sigma}\right)\right\}^{-1}
\end{aligned}
$$

である.すなわち, 中性化深さ $x_{i}$ はワイブル分 布 $W\left(\mu\left(T_{i}\right), \sigma^{2}\left(T_{i}\right)\right)$ に従うことになる。ただし, $\mu\left(T_{i}\right), \sigma^{2}\left(T_{i}\right)$ はワイブル分布の期待值, および分散で あり

$$
\mu\left(T_{i}\right)=\rho\left(T_{i}\right)^{1 / \kappa} \Gamma\left(\kappa^{-1}+1\right)
$$




$$
\begin{aligned}
& \sigma^{2}\left(T_{i}\right) \\
& \quad=\rho\left(T_{i}\right)^{2 / \kappa}\left\{\Gamma\left(\frac{2}{\kappa}+1\right)-\Gamma^{2}\left(\frac{1}{\kappa}+1\right)\right\}(30
\end{aligned}
$$

と表せる. $\Gamma(\cdot)$ はガンマ関数である.さらに，中性化 深さの確率分布を表す分布関数 $H\left(x_{i} \mid T_{i}, \boldsymbol{z}_{i}\right)$ は

$$
H\left(x_{i} \mid T_{i}, \boldsymbol{z}_{i}\right)=1-\exp \left\{-\frac{x_{i}^{\kappa}}{\rho\left(T_{i}\right)}\right\}
$$

と表せる.この時，リスク管理水準を $\varepsilon \times 100 \%$ とした VaR (Value at Risk) 指標 $\hat{x}_{i}(\varepsilon)$ は

$$
H\left(\hat{x}_{i}(\varepsilon) \mid T_{i}, \boldsymbol{z}_{i}\right)=1-\varepsilon
$$

を満足するような $\hat{x}_{i}(\varepsilon)$ として定義できる. すなわち， 経過時間 $T_{i}$ において，それを超えるような中性化深さ が出現するような超過確率が $\varepsilon$ となるような臨界的な 中性化深さを表す. また, 経過時間 $T_{i}$ における期待中 性化深さ $E\left[x_{i}\right]$ は, 式 (30a) より

$$
E\left[x_{i}\right]=\Gamma\left(\frac{1}{\kappa}+1\right) \exp \left(\frac{\ln T_{i}-\boldsymbol{\theta}^{\prime} \boldsymbol{z}_{i}}{\kappa \sigma}\right)
$$

となる.さらに，上式において経過時間 $T_{i}$ の值を変化 させ, 経過時間 $T_{i}$ と期待中性化深さ $E\left[x_{i}\right]$ の関係を表 した曲線を「中性化期待值パス」と呼ぶ。中性化期待 值パスは，統計的関係を表したものであり，ある特定 の中性化曲線を示したものではないことを断っておく.

\section{b) 余寿命指標}

中性化が鉄筋の位置まで進展すると鉄筋の腐食が始 まる，したがって，中性化深さの管理水準として，鉄 筋のかぶり厚 $\bar{X}$ を採用することができる．中性化が管 理水準 $\bar{X}$ まで到達するまでの経過時間を寿命 $\eta_{i}$ と呼 ぶこととする. 現時点において, 部材 $i$ の中性化が管理 水準にまで到達せず, 寿命 $\eta_{i}$ に対して $\eta_{i}>T_{i}$ が成立 している場合を考える. 中性化が管理水準 $\bar{X}$ まで到達 していないという条件の下で，今後さらに $\tau$ 以上の期 間にわたって当該施設を補修しないで供用できる条件 付確率（以下，余寿命分布と呼ぶ） $\tilde{F}\left(\tau \mid \bar{X}, T_{i}\right)$ は

$$
\tilde{F}_{i}\left(\tau \mid \bar{X}, T_{i}\right)=\operatorname{Pr}\left\{\eta_{i} \geq T_{i}+\tau \mid \bar{X}, \eta_{i} \geq T_{i}\right)
$$

と定義できる. すなわち, 確率 $\tilde{F}\left(\tau \mid \bar{X}, T_{i}\right)$ は, 経過時 間 $T_{i}$ の部材 $i$ の管理水準 $\bar{X}$ に到達寸るするまでの余寿 命が $\tau$ 以上となる確率を表している.さらに，生存確 率 $S_{t}\left(T_{i} \mid \bar{X}, \boldsymbol{z}_{i}\right)$ を用いれば, 余寿命分布 $\tilde{F}\left(\tau \mid \bar{X}, T_{i}\right)$ は

$$
\begin{aligned}
& \tilde{F}_{i}\left(\tau \mid \bar{X}, T_{i}\right)=\frac{S_{t}\left(T_{i}+\tau \mid \bar{X}, \boldsymbol{z}_{i}\right)}{S_{t}\left(T_{i} \mid \bar{X}, \boldsymbol{z}_{i}\right)} \\
& =\frac{1-\exp \left\{-\lambda_{i}\left(\bar{X}, \boldsymbol{z}_{i}\right)\left(T_{i}+\tau\right)^{-\beta}\right\}}{1-\exp \left\{-\lambda_{i}\left(\bar{X}, \boldsymbol{z}_{i}\right) T_{i}^{-\beta}\right\}}
\end{aligned}
$$

と表される.ただし， $S_{t}\left(T_{i} \mid \bar{X}, z_{i}\right)$ は，加速劣化八ザー ドモデルの生存関数であり, 式(10a) で表される. 2.(4) で言及したように，中性化が管理水準に到達した時点 でコンクリートの補修を実施する場合, 余寿命分布は, 補修タイミングの確率分布を表している。ささらに, 中
性化が管理水準以上に進展する超過確率（図-1 の斜線 部分の面積）を $v$ に設定すれば，それと対応する補修 タイミング $\tau^{*}$ は

$$
\tilde{F}_{i}\left(\tau^{*}\right)=1-v
$$

を満足するような $\tau^{*}$ として求まる. なお，期待余寿命 (Remaining Mean Distribution) は, 部分積分により

$$
\begin{aligned}
R M D\left(T_{i}\right) & =E\left[\eta_{i}-T_{i} \mid \eta_{i} \geq T_{i}\right] \\
& =\frac{\int_{T_{i}}^{\infty}\left(u-T_{i}\right) d \tilde{F}_{i}(u) d u}{\tilde{F}_{i}\left(T_{i}\right)} \\
& =\frac{1}{\tilde{F}_{i}\left(T_{i}\right)} \int_{T_{i}}^{\infty} \tilde{F}_{i}(u) d u
\end{aligned}
$$

と表される. 初期時点における部材 $i$ の期待寿命は

$$
R M D(0)=\lim _{\varepsilon \rightarrow 0} \int_{\varepsilon}^{\infty} \tilde{F}_{i}(u) d u
$$

となる。

\section{4. 適用事例}

\section{(1) 概要}

大阪市水道局においては，過去約 20 年間にわたって， 浄水場の耐震構造調查に伴い, 浄水場コンクリート構 造物の劣化状態に関する詳細調査を実施してきた。こ れらの調査においては, 圧縮強度, 中性化深さ, 鉄筋腐 食, 鉄筋引張強度, 超音波測定 (ひび割れ深さ), シュ ミットハンマー調查等を実施している。このうち, 圧縮 強度, 中性化深さに関しては, 対象とするコンクリー 卜構造物からコアサンプルを無作為に抽出し, 損傷の 実態について調査している. 対象とする浄水場施設は, 1910 年代から 20 年代に築造された柴島浄水場, およ び 1940 年代から 60 年代に築造された施設群に大別さ れる。このうち，1945 年以降に築造された浄水場施設 は, 品質管理が困難な時代背景の中で築造されたため, コンクリート構造物が経過年数に伴い早期劣化する可 能性がある. 大阪市水道局が蓄積した詳細調査の中で, 表-1 に示すような調查結果を用いて加速劣化ハザード モデルを推計することとした，推計に用いたデータ数 は $n=236$ である.コンクリートコアサンプルの構造 特性を表す変数として

$$
\begin{aligned}
& \delta_{i}^{1}= \begin{cases}0 & \text { 万過池以外の場合 } \\
1 & \text { 万過池の場合 }\end{cases} \\
& \delta_{i}^{2}= \begin{cases}0 & 1945 \text { 年以前の築造物 } \\
1 & 1945 \text { 年以降の築造物 }\end{cases}
\end{aligned}
$$

という 2 種類のダミー変数を用いることとした。した がって, 推計に用いた加速劣化八ザードモデルは

$$
\begin{aligned}
& y_{i}=\alpha \ln x_{i}+\theta_{0}+\theta_{1} \delta_{i}^{1}+\theta_{2} \delta_{i}^{2}+\sigma w_{i} \\
& (i=1, \cdots, 236)
\end{aligned}
$$

と表される.ただし， $\theta_{0}$ は定数項である. 
表-1 対象データ

\begin{tabular}{ccccccc}
\hline 施設 & $\begin{array}{c}\text { 調查 } \\
\text { 年次 }\end{array}$ & 築造年 & $\begin{array}{c}\text { 経過 } \\
\text { 年数 }\end{array}$ & $\begin{array}{c}\text { データ } \\
\text { 数 }\end{array}$ & $\delta^{1}$ & $\delta^{2}$ \\
\hline $\mathrm{A}$ & 1993 & 1967 & 26 & 66 & 0 & 1 \\
$\mathrm{~B}$ & 1996 & 1969 & 27 & 9 & 0 & 1 \\
$\mathrm{C}$ & 1988 & 1967 & 21 & 30 & 0 & 1 \\
$\mathrm{D}$ & 1989 & 1955 & 34 & 7 & 0 & 1 \\
$\mathrm{E}$ & 1989 & 1962 & 27 & 7 & 0 & 1 \\
$\mathrm{~F}$ & 1989 & 1922 & 67 & 33 & 0 & 0 \\
$\mathrm{G}$ & 1986 & 1914 & 72 & 2 & 0 & 0 \\
$\mathrm{H}$ & 1986 & 1914 & 72 & 1 & 0 & 0 \\
$\mathrm{I}$ & 1986 & 1949 & 37 & 2 & 0 & 1 \\
$\mathrm{~J}$ & 1990 & 1962 & 28 & 8 & 1 & 1 \\
$\mathrm{~K}$ & 1996 & 1967 & 29 & 13 & 0 & 1 \\
$\mathrm{~L}$ & 1985 & 1958 & 27 & 12 & 0 & 1 \\
$\mathrm{M}$ & 1985 & 1955 & 30 & 2 & 0 & 1 \\
$\mathrm{~N}$ & 1993 & 1963 & 30 & 3 & 0 & 1 \\
$\mathrm{O}$ & 1993 & 1963 & 30 & 0 & 1 & 1 \\
$\mathrm{P}$ & 1991 & 1964 & 27 & 0 & 1 & 1 \\
$\mathrm{Q}$ & 2007 & 1958 & 49 & 15 & 0 & 1 \\
$\mathrm{R}$ & 2007 & 1958 & 49 & 20 & 1 & 1 \\
$\mathrm{~S}$ & 2007 & 1960 & 47 & 3 & 0 & 1 \\
$\mathrm{~T}$ & 2007 & 1958 & 49 & 3 & 0 & 1 \\
\hline
\end{tabular}

注) $\delta_{1}$ は， 万過池の場合は 1 を，そうでない場合は 0 をと るダミー変数である.

\begin{tabular}{ccccc}
\multicolumn{5}{c}{ 表-2 推計結果 } \\
\hline$\alpha$ & $\theta_{0}$ & $\theta_{1}$ & $\theta_{2}$ & $\sigma$ \\
\hline 0.6791 & 1.553 & 0.3138 & -0.9383 & 0.1603 \\
$(5.804)$ & $(3.383)$ & $(9.552)$ & $(-31.32)$ & $(-)$ \\
\hline
\end{tabular}

\section{(2) 推計結果}

以上のデータベースに基づいて加速劣化ハザードモ デルを推計した。その結果を表-2 に示している. 同表 の括弧内の数值は $t$-值を示している.いずれのパラ メータも各説明変数が説明力を有さないという仮説は 有意水準 $95 \%$ で棄却される。以上の推計結果より, 中 性化の進行プロセスは式 $(2 \mathrm{a})$ より,

$$
\begin{aligned}
& x_{i}=\exp \left(\frac{-B_{i}}{0.6791}\right) t_{i}^{1.47} \\
& B_{i}=1.553+0.3138 \delta_{i}^{1}-0.9383 \delta_{i}^{2}+0.1603 w_{i} \\
& (i=1, \cdots, 236)
\end{aligned}
$$

と表される. 以上の推計結果より，乃過池施設であるか どうかを表すダミ一変数 $\delta_{i}^{1}$ の係数は 0.3138 であり，ろ 過池施設の方が他の施設より中性化速度が遅い. 1945 年以降に建設された施設であるかどうかを表すダミー 変数 $\delta_{i}^{2}$ の係数が -0.9383 となっており, 戦後の復興過 程で建設された浄水場コンクリート施設の中性化過程 は, 戦前の浄水場コンクリートより中性化速度が早い ことが理解できる. 一方, 中性化過程がルート $t$ 則を満 足する場合, 加速度パラメータの推計值は $\alpha=2.0$ とな る. しかしながら, 分析対象として用いた浄水場コンク リート施設のサンプルに関しては, 加速度パラメータの 推計值は $\alpha^{*}=0.6791$ であり, ルート $t$ 則を満足してい
ない. 実際に, 式 (24) で評価される仮説検定統計量は $\xi=126.7$ となり, その一方で, 自由度 $\gamma=5$ の $\chi^{2}$ 分布 における有意水準 $95 \%$ の臨界值は $\chi_{(100-95)}^{2}(5)=11.07$ となる。したがって，明らかに条件式 $\xi \geq \chi_{(100-95)}^{2}(5)$ を満足するために, 統計的検定においてもルート $t$ 則 は棄却される。

以上は，あくまでも限られた長期のサンプルを対象 とした分析結果であり，この分析結果は対象コンクリー 卜に対してのみ適用可能であることは言うまでもない. さらに, 提案した加速劣化ハザードモデルは, 確率誤 差項の確率分布としてパラメトリックな標準ガンベル 分布を想定しており, 仮説検定の結果が確率誤差項分 布に関する特定化誤差の影響を受けている可能性があ る.このような理由により, 加速劣化ハザードモデル を用いた仮説検定によりルート $t$ 則に関する仮定が棄 却されたからといって, 直ちにコンクリート中性化過 程に関わるルート $t$ 則（特に短・中期間を対象とした ルート $t$ 則）の妥当性が否定されるものではない. しか し, 現実のコンクリート中性化に関する長期的進行過 程は, 炭酸イオンのコンクリート内拡散理論だけでな く, 多様な要因が関連していることが推察できる.コ ンクリート中性化過程に対しては, 力学的進行プロセ スに関して，さらに知見を蓄積することが必要である. 本研究の 1 つの成果は, コンクリートのかぶり深さの 設計指針として用いられてきた中性化過程のルート $t$ 則 の統計的妥当性に関する仮説検定の方法論を開発した 点にある. 今後, コンクリート中性化過程のモデル化 に関しては，継続してサンプル数を蓄積することによ り，ルート $t$ 則に関する統計的妥当性に関して検討を積 み重ねることが必要である。

\section{(3) リスクマネジメント指標の算定結果}

\section{a) 中性化深さ指標}

初期時点から $T_{i}$ 年が経過した時点における中性化深 さ $x_{i}$ は条件付確率密度関数 $(28)$ を用いて表すことがで きる. 表-2 の推計結果を用いれば，具体的な中性化深 さの条件付き確率分布は,

$$
f_{x_{i}}\left(x_{i} \mid T_{i}, \boldsymbol{z}_{i}\right)=\frac{4.235 x_{i}^{3.235}}{\rho_{i}\left(T_{i}\right)} \exp \left(-\frac{x_{i}^{\kappa}}{\rho_{i}\left(T_{i}\right)}\right)
$$

と表すことができる。ただし，

$$
\begin{aligned}
& \kappa=4.235 \\
& \rho_{i}\left(T_{i}\right)=\left\{\exp \left(\frac{\Theta_{i}-\ln T_{i}}{0.1603}\right)\right\}^{-1} \\
& \Theta_{i}=1.553+0.3138 \delta_{i}^{1}-0.9383 \delta_{i}^{2}
\end{aligned}
$$

である。また，期待值，および分散は，

$$
\begin{aligned}
& \mu=0.9093 \rho\left(T_{i}\right)^{1 / 4.235} \\
& \sigma^{2}=0.05870 \rho\left(T_{i}\right)^{2 / 4.235}
\end{aligned}
$$




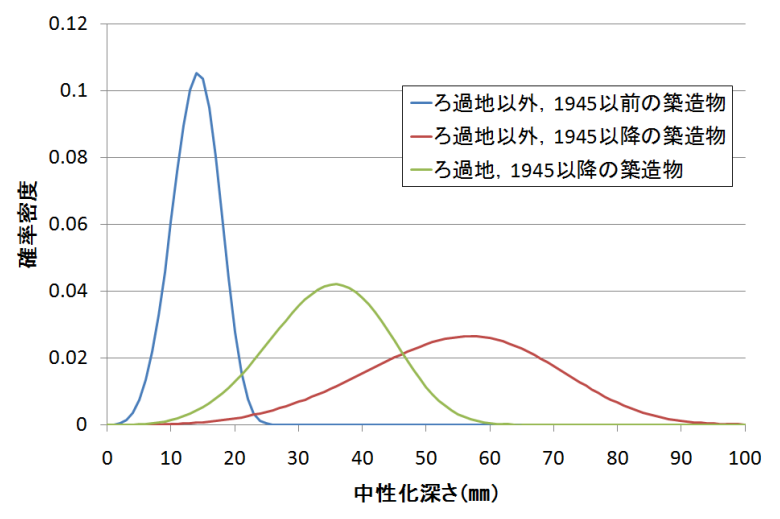

図-2 中性化深さの確率分布 $(30$ 年後)

と表せる. 図-2 は，初期時点から一定の時間 30 年が経 過した時点 $\left(T_{i}=30\right)$ における中性化深さ分布を図示し た結果である。実際に，大阪市においては，表面被覆工 事の頻度, メーカー保証期間, 点検実績などを勘案した 上で，補修頻度を約 30 年と想定している。同図は，横 軸に示した任意の中性化深さを対象として，30 年を経 過した時点で, その中性化深さを超えない確率密度関 数を図示している. 図から明らかなように, 中性化の 進行が最も遅いのは 1945 年以前のろ過池以外であり, ついで 1945 年以降のろ過池, 1945 年以降のろ過池以 外の順となっている。これは当然ながら 4.(2) の推計 結果と整合的である。また，式 (44a)より，それぞれの 30 年経過時点における中性化深さの期待值は $13.8 \mathrm{~mm}$, $34.7 \mathrm{~mm}, 55.0 \mathrm{~mm}$ である。

リスク管理水準を $5 \%$ とした中性化深さに関する VaR (Value at Risk) 指標 $\hat{x}_{i}(0.05)$ は, 式 $(31),(32) よ り$,

$$
1-\exp \left(-\frac{x_{i}^{\kappa}}{\rho\left(T_{i}\right)}\right)=1-0.05
$$

を満足するような $\hat{x}_{i}(0.05)$ として定義できる. 一方で, 上述した期待值は, VaR (Value at Risk) 指標 $\hat{x}_{i}(0.50)$ に他ならない.ただし，このことは 30 年経過時点で全 体の $50 \%$ が管理指標を超える中性化深さに到達してい ることを意味する. 期待值は概念的に理解しやすく, 設 計においては重要な指標となり得るが, 現実の構造物 における中性化速度の分散の大きさを考慮すれば, 維持 管理の実務においては有用な管理指標であるとは思え ない. 具体的に, 図-2 の 1945 年以前のろ過池以外 (青 色), 1945 年以降のろ過池 (緑色), 1945 年以降のろ過池 以外 (赤色) に対して, $\hat{x}_{i}(0.95)$ を算出すると, $19.7 \mathrm{~mm}$, 49.4mm，78.4mm となる。なお，これらの值は図-2の それぞれの確率分布の上限 $5 \%$ の面積を与える中性化 深さに対応する.

図-3 は経過時間 $T_{i}$ と期待中性化深さ $E\left[x_{i}\right]$ との関係 を示した中性化期待值パス (式 (33) 参照) を示してい る. 1945 年以前と以降で中性化深さの進行に大きな差

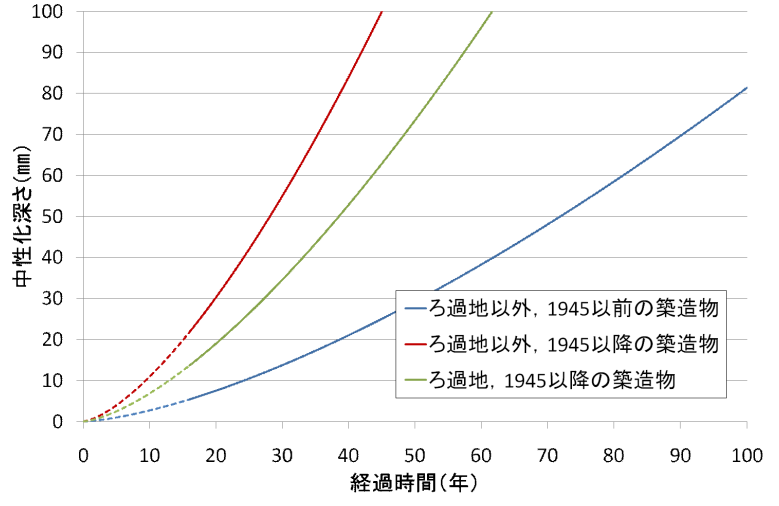

注）短・中期（数ヶ月〜 15 年程度）を対象とした中性化過 程を点線で示す。

\section{図-3 期待中性化深さ}

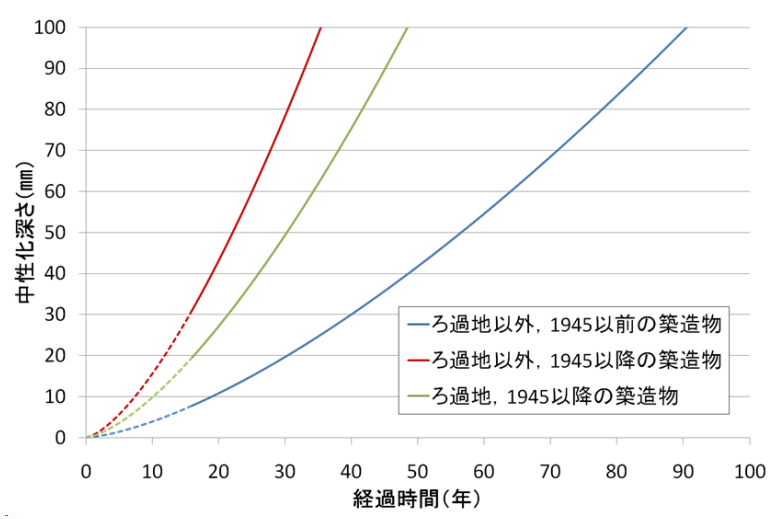

注）短・中期（数ヶ月〜 15 年程度）を対象とした中性化過 程を点線で示す.

図-4 リスク管理水準 5\% の中性化深さ

異があること, 中性化深さが経年とともに加速的に進 行していること，が見て取れる.さらに図-4には，経 過時間 $T_{i}$ とリスク管理水準 $5 \%$ の中性化深さとの関係 を示す. 土木構造物の維持管理を実行する実務におい ては，このような期待中性化深さ $E\left[x_{i}\right]$ を念頭に入れ ながら, 経過年数に応じたリスク管理指標 (VAR) 指標 $\hat{x}_{i}(0.05)$ で補修実施に対する意思決定を行うことが重 要である. また, 参考までに加速度パラメータの推計 值を $\alpha=2.0$ に設定し, ルート $t$ 則に従う中性化過程 を記述したものを図-5 に示す.これまで指摘してきた 通り，20 年を経過した時点から中性化深さの進行が緩 やかになることが理解できる.

\section{b) 余寿命指標}

適用事例として取り上げる净水場施設には, 戦前に 建設された施設も含まれている。このような施設に関 しては, 鉄筋までのコンクリートかぶり厚に関するデー タが存在しないが, 非破壊試験によりかぶり厚を推計 することができる. 浄水場施設を点検するためには, 浄 


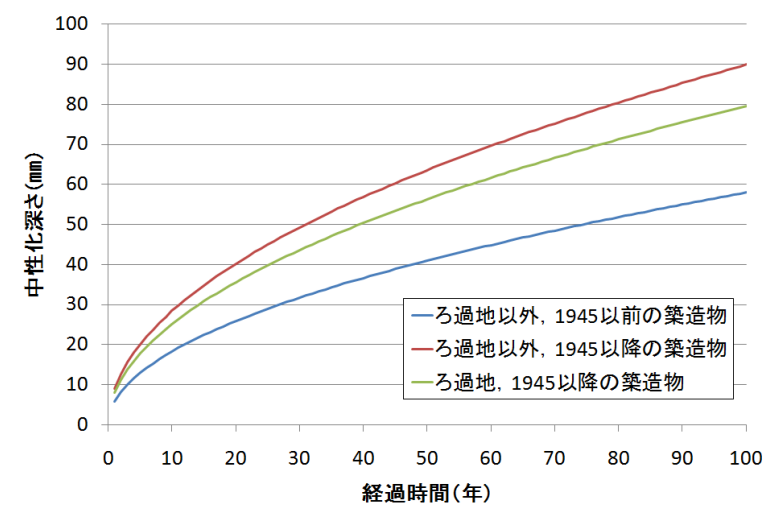

図-5 期待中性化深さ (ルート $t$ 則 : $\alpha=2.0$ )

水場の供用を停止することが必要となる．ただし，点検 のために多大な時間を要することは不可能であり, 中 性化の状態を目視点検で判定せざるを得ない，中性化 が鉄筋の位置まで進展している場合，コンクリート版 の補修を実施する必要がある。それ以外の場合，中性 化が発生したコンクリート施設を必ずしも直ちに補修 する必要はない. アセットマネジメント上は, 補修を行 うまでどの程度の期間にわたって中性化の進展を許容 できるかという判断が重要となる，その場合，式 (35) で示した余寿命分布 $\tilde{F}\left(\tau \mid \bar{X}, T_{i}\right)$ が重要なマネジメント 情報となる. 余寿命指標を再掲すれば,

$$
\begin{aligned}
& \tilde{F}_{i}\left(\tau \mid \bar{X}, T_{i}\right)=\frac{1-\exp \left\{-\lambda_{i}\left(T_{i}+\tau\right)^{-6.238}\right\}}{1-\exp \left\{-\lambda_{i} T_{i}^{-6.238}\right\}} \\
& \lambda_{i}=\exp \left(\frac{0.6791 \ln x_{i}+\Theta_{i}}{0.1603}\right) \\
& \Theta_{i}=1.553+0.3138 \delta_{i}^{1}-0.9383 \delta_{i}^{2}
\end{aligned}
$$

と表される。いま，施設の建設年度から $T_{i}$ 年を経過し た時点で，コンクリート版を目視点検したとしよう。そ の段階で, コンクリート版の中性化の発生の有無がデー タベースに記載される，鉄筋の腐食が発生している場 合, 直ちに補修が実施される。中性化が発生している が，鉄筋の腐食まで進展していないことが判明したと 考える. この時, 余寿命指標は, 中性化管理水準 (コン クリートのかぶり厚) を $\bar{X} \mathrm{~mm}$ とした場合, この施設 が当該時点から, 中性化が管理水準までに到達するま での所要時間 (余寿命) $\tau$ の確率分布として定義するこ とができる. 図-6 には $T_{i}=10$ 年, $\bar{X}=50 \mathrm{~mm}$ とし た場合における余寿命分布を求めた結果を示している. なお，本研究で対象としたコンクリートコアサンプル のかぶり厚の平均值は $48.2 \mathrm{~mm}$ である. 中性化が管理 水準以上に進展する超過確率を $v=0.05$ に設定すれば, 1945 年以前のろ過池以外 (青色), 1945 年以降のろ過池 (緑色), 1945 年以降のろ過池以外 (赤色) に対する補修 タイミング $\tau^{*}$ は， $46.5 ， 20.2 ， 12.1$ 年後となる. 一方 で, 期待余寿命に関して同様に算出すると, 現時点に

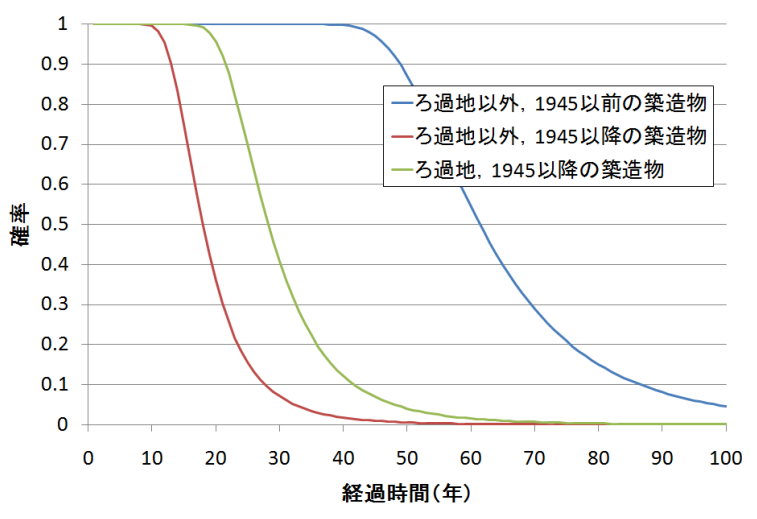

図-6 余寿命分布 $\left(T_{i}=10\right.$ 年, $\left.\bar{X}=50 \mathrm{~mm}\right)$

おいて，65.6，30.5，19.6 年であり，とりわけ 1945 年 以降の築造物に関しては, 管理水準に基づく補修タイ ミングと顕著な差が確認できない（中性化管理水準に 到達するまでに, 中性化の進行が上位 $5 \%$ のサンプルと 平均的なサンプルとの間で 10 年も差異がない)。これ は, 1945 年以降の築造物の中性化深さが経過年数とと もに加速的に進展することに起因するが, 補修タイミ ングの遅延には数年程度の猶予しか許されないことを 示唆している.

\section{5. おわりに}

本研究では, 浄水場施設の更新時点に収集されたコ アサンプルを用いてコンクリート版の中性化速度を予 測する方法を提案した。 その際, 長期アセットマネジ メントにおいて, ルート $t$ 則に基づいた劣化予測式を用 いることの問題点を指摘するとともに, 中性化深さの 測定データに基づいて, 長期的な中性化過程を解析す るための加速劣化ハザードモデルを提案した. さらに, ルート $t$ 則に関する統計的仮説検定の結果, 少なくとも 対象データに関してルート $t$ 則は棄却され, 現実の中 性化過程はルート $t$ 則より, 加速して進行することが判 明した. 本研究で提案した加速劣化ハザードモデルは, 浄水場施設に限定されずに, コンクリート構造物の中 性化予測に幅広く適用が可能である. しかし, 加速劣 化八ザードモデルの実用性を向上させるために, 今後 に残された研究課題が存在する. 第 1 に, 本研究で用 いた浄水場施設のデータに関する限り, コンクリート の長期的な中性化予測にルート $t$ 則は適用できないこ とが判明した. 今後は, コンクリートの中性化過程に 関するデータを蓄積し, ルート $t$ 則の妥当性に関する 知見を蓄積することが必要である. また, 中性化が加 速化されている力学的メカニズムについて検討する必 要がある. 第 2 は, 比例八ザードモデルを用いたハイ ブリッド型劣化予測モデルに関して理論的, 経験的な 
展開が必要である. 力学モデルをベースラインモデル とするような比例ハザードモデルを開発することによ り, 力学モデルの統計的推計が可能となる.このよう なハイブリッドモデルは，コンクリートの中性化のみ ならず，さまざまな確定的劣化予測モデルの統計的推 計に適用が可能である. 第 3 に，加速劣化ハザードモ デルにおける確率誤差項の確率分布として，パラメト リックな確率分布関数を想定しており，仮説検定の結 果が確率誤差項分布に関する特定化誤差の影響を受け ている可能性がある.今後, 検査サンプルを蓄積する ことにより，ルート $t$ 則の経験的有効性に関する経験的 研究を積み重ねることが重要である. 第 4 に, 加速劣 化ハザードモデルは, ベースラインモデルを想定して いるため, 比較的限定されたデータを用いて推計でき るという利点がある。今後, 継続的に点検データが蓄 積されれば，加速劣化ハザードモデルの推計結果を更 新することが必要である. 加速劣化ハザードモデルの ベイズ更新に関する手法の開発が求められる.

なお, 本研究の一部は文部科学省「若手研究者の自 立的研究環境整備促進」事業によって大阪大学グロー バル若手研究者フロンティア研究拠点にて実施された.

\section{参考文献}

1) 日本水道協会 : 水道施設更新指針, 2004 .

2) 大阪市水道局工務部（計画担当）: アセットマネジメン 卜に基づく浄水施設の戦略的な施設保全の推進に向けた 調査検討について, 2008.

3) 厚生労働省健康局水道課 : 水道事業におけるアセットマ ネジメントに関する手引き (案) の策定について, 2009.

4) 北野陽一郎, 山崎弘太郎, 江口勝彦, 宮崎博明, 赤木信 雄, 安野貴人, 白濱輝幸 : 浄水施設整備へのアセットマ ネジメントの適用, 土木学会第 64 回年次学術講演会, 2009.

5) 岸谷孝一 : 鉄筋コンクリートの耐久性, 鹿島建設研究所 出版部, 1963.

6) Wierig, H. J.: Longtime Studies on the Carbonation of Concrete under Normal Outdoor Exposure, Proceedings of the RILEM Seminar on the Durability of Concrete Structures under Normal Exposure, pp.239244, 1984.

7）依田彰彦, 横室隆 : 各種セメントを用いたコンクリート の中性化深さ, コンクリート工学年次論文報告集, Vol.9, pp.327-332, 1987.

8) 大賀宏行, 長㴰重義 : 促進試験によるコンクリートの中 性化深さの予測と評価, 土木学会論文集, No.390/V-8, pp.225-233, 1988.

9）佐伯竜彦, 大賀宏行, 長龍重義 : コンクリートの中性化 機構解明，土木学会論文集，No.413/V-12，pp.99-108, 1990.

10）魚本健人, 高田良平: コンクリートの中性化速度に及ぼ 寸要因, 土木学会論文集, No.442/V-17, pp.109-118, 1992.

11) 関口司, 魚本健人, 高田良章, 渡辺正: ニューラルネット ワークを用いたコンクリート実験のデータ解析に関する 研究, 土木学会論文集, No.460/V-18, pp.65-74, 1993.

12）伊井克, 大賀宏行 : 統計的手法によるコンクリートの 中性化深さの評価, 土木学会第 52 回年次学術講演会, pp.752-753, 1997.

13）伊代田岳史, 矢島哲司, 魚本健人 : コンクリートのひび 割れが中性化速度に及ぼす影響, コンクリート工学年次 論文報告集，Vol.20，pp.979-984， 1998.

14）依田彰彦: 40 年経過した高炉セメントコンクリートの中 性化と仕上げ材の効果，セメント・コンクリート論文集， No.56, pp.449-454, 2002.

15）長谷川拓哉, 千歩修 : 文献調査に基づく屋外の中性化進 行予測, コンクリート工学年次論文集, Vol.28, pp.665670, 2006.

16) 土木学会 335 委員会: 簡略式を用いた劣化予測, 構造物表 面のコンクリート品質と耐久性能検証システム研究小委員 会成果報告書，コンクリート技術シリーズ, pp.246-266, 2008.

17) Papadakis, V. G., Vayenas, C. G. and Fardis, M. N.: Fundamental modeling and experimental investigation of concrete carbonation, ACI Material Journal, pp.363-373, Vol.88, No.4, 1991.

18) Saetta, A. V., Schrefler, B. A. and Vitaliani, R. V.: The carbonation of concrete and the mechanisms of moisture, heat and carbon dioxide flow through porous materials, Cement and Concrete Research, Vol.23, pp.761-772, 1993.

19) Saetta, A. V., Schrefler, B. A. and Vitaliani, R. V.: 2-D model for carbonation and moisture/heat flow in porous materials, Cement and Concrete Research, Vol.25, pp.1703-1712, 1995.

20) 長田光正, 植木博, 山崎之典, 村上正明 : アルカリ成分 に着目したコンクリート部材の炭酸化シュミレーション 解析，コンクリート工学年次論文報告集，Vol.19, No.1, pp.793-798, 1997.

21) 松本洋一, 植木博, 山崎之典, 村上正明: 炭酸カルシウム の再溶解を考慮した炭酸化反応に関するモデル解析，コ ンクリート工学年次論文報告集, Vol.20, No.1, pp.961996, 1998.

22) 石田哲也, 前川宏一: 物質移動則と化学平衡論に基づく空 隙水の $\mathrm{pH}$ 評価モデル, 土木学会論文集, No.648/V-47, pp.203-215, 2000.

23）吉田浩也, 宮崎慎也, 佐伯竜彦, 大下英吉 : セメント系 材料における炭酸化による $\mathrm{pH}$ 遷移に関する解析的研究, コンクリート工学年次論文報告集, Vol.23, pp.481-486, 2001.

24) 山本耕児, 宮崎慎哉, 大矢英吉 : 濃度依存型の炭酸化反 応速度定数と $\mathrm{pH}$ 遷移に関する研究, コンクリート工学 年次論文集, Vol.24, No.1, pp.765-770, 2002.

25）土木学会 328 委員会主催 : コンクリート構造物のヘルス モニタリング・シンポジウム, 2007.

26) 白川敏夫, 鳥添洋治, 麻生実 : コンクリートの中性化と 湿度の関係に関する研究，コンクリート工学年次論文集， Vol.18, No.1, pp.723-728, 1996.

27) 小田原暁, 白川敏夫, 鳥添洋治, 麻生実 : コンクリート 中への酸素ガスの拡散について（空隙の影響について）， 日本建築学会学術講演梗概要 A, pp.239-240, 1994.

28) 土木学会 : コンクリート標準示方書 [維持管理編], 2001.

29）仁平達也, 曽我部正道, 谷村幸裕, 東川孝治: ドリル法に よる中性化深さ測定の実構造物への適用の検討，コンク リート工学年次論文集, Vol.26, No.1, pp.2025-2030, 2004.

30) 谷村幸裕, 長谷川雅志, 曽我部正道, 佐藤勉 : 鉄道 RC ラーメン高架橋の中性化に関する而久性照查法の適用に関 する研究，土木学会論文集，No.760/V-63，pp.147-157, 2004.

31) Shin, H.C. and Madanat, S.: Development of a stochastic model of pavement distress initiation, Journal of Infrastructure Planning \& Management, 
No.744/IV-61, pp.61-67, 2003.

32) 青木一也, 山本浩司, 小林潔司: 劣化予測のための八 ザードモデルの推計, 土木学会論文集, No.791/VI-67, pp.111-124, 2005.

33) 津田尚扸, 貝戸清之, 青木一也, 小林潔司: 橋梁劣化予 測のためのマルコフ推移確率の推定, 土木学会論文集, No.801/I-73, pp.68-82, 2005.

34）貝戸清之, 小林潔司: マルコフ劣化ハザードモデルのベイ ズ推定，土木学会論文集 A, Vol.63, No.2, pp.336-355, 2007.

35）青木一也, 山本浩司, 津田尚胤, 小林潔司: 多段階ワイブ ル劣化ハザードモデル，土木学会論文集，No.798/VI-68， pp.125-136, 2005.

36）下村泰造, 小濱健吾, 貝戸清之, 小林潔司 : 空港舗装ア セットマネジメントのためのハイブリッド型地盤沈下モ デル, 土木学会論文集 F, Vol.64, No.4, pp.463-482, 2008.

37) 中村剛 : Cox 比例ハザードモデル, 医療統計学シリーズ, 朝倉書店, 2001.
38) Lancaster, T.: The Econometric Analysis of Transition Data, Cambridge University Press, 1990.

39) Gourieroux, C.: Econometrics of Qualitative Dependent Variables, Cambridge University Press, 2000.

40) Lee, E. T. and Wang, J. W.: Statistical Methods for Survival Data Analysis, John Wiley \& Sons, 2003.

41) Cox, D.R. and Oakes, D.: Analysis of Survival Data, Chapman \& Hall/CRC, 1998.

42 ) 安野貴人, 保田敬一:土木構造物の維持管理と劣化進行の ハザード形状, 応用力学論文集, Vol.10, pp.1019-1026, 2007.

43) 磯田和男, 大野豊 : 数值計算ハンドブック, オーム社, 1990.

44）森棟公夫：計量経済学, 東洋経済新報社, 1999.

(2009.12.18 受付)

\title{
AN ACCELERATED DETERIORATION HAZARD MODEL: APPLYING FOR CONCRETE CARBONATION PROCESSES
}

\author{
Takashi TANAKA, Yuji FUJIMORI, Kiyoyuki KAITO, Kiyoshi KOBAYASHI \\ and Takato YASUNO
}

\begin{abstract}
The carbonation of concrete components has become on of the major subjects in the asset management of water treatment facilities. The root- $t$ formula, which postulates that the carbonation depth is proportional to the root of the exposure time length, has been the basic hypothesis in explaining the short- and mediumterm carbonation processes. Yet, no sufficient data sources are available so far to describe the longterm carbonation. In this paper, the accelerated hazard model is presented to forecast the long-term carbonation processes based upon the observation sets of carbonated concrete samples. As far as our dataset is concerned, the hypothesis of the root- $t$ formula is statistically rejected. The carbonation has progressed faster than expected by the root- $t$ formula.
\end{abstract}

